\title{
Fruit intake and obesity Fruit and vegetables consumption and obesity in Brazil
}

\author{
Rachel Helena Vieira Machado ${ }^{1}$, Rubens Feferbaum², Claudio Leone ${ }^{3,4}$
}

DOI: http://dx.doi.org/10.7322/jhgd.119293

\begin{abstract}
Introduction: Obesity affects more than half of the adult population and correlates with the development of chronic and psychosocial diseases. The consumption of fruits and vegetables (FV) is a protective factor for obesity, but their consumption is often below the recommendations.
\end{abstract}

Objective: To identify the level of fruit consumption in human development cycles, as well as the data on the association of fruit consumption with excess weight in Brazil.

Methods: A non-systematic literature review on the Virtual Health Library (VHL) databases for the period 2005 to 2015. A total of 23 studies were selected in the English and Portuguese languages, according to the study design and population group. Only cohorts and cross sections studies in Brazil were selected. Appropriate FV consumption was considered to be $400 \mathrm{~g} /$ day or a frequency of 5 servings/day (3 servings/day of fruits), and overweight was evaluated according to each age group and development cycle.

Results: The average consumption for pregnant women was found to be $350 \mathrm{~g} /$ day; an inverse relationship was found between total fibre consumption and gestational weight gain. The average consumption of FV for children and adolescents has remained between $30 \%$ and $40 \%$, consumption falling with increasing age. Vigitel data between 2006 and 2014 shows an increase in the prevalence of adequate consumption of FV for adults and seniors according to gender, age and education. Appropriate consumption tripled during this period. There was an association between fruit consumption and weight loss, increased risk of obesity, abdominal obesity, hypertriglyceridemia and presence of metabolic syndrome (SM).

Conclusions: The prevalence of adequate consumption of FV is low in all regions of Brazil and among all age groups, the highest prevalence is among women and increases with the advance of age, higher education level and higher socioeconomic status. Adequate fruit consumption correlates to weight loss and/or weight gain control of individuals.

Key words: Fruit consumption, obesity/overweight, Brazil, pregnancy, children, teens, seniors, adults.

\section{INTRODUCTION}

Obesity is characterized by the chronic accumulation of fat tissue, regionalized or widespread, a combination of genetic factors, environmental and behavioural factors ${ }^{1}$. The National Survey on Health (NSH/PNS), shows that $57 \%$ of the population over 18 years old in Brazil presents as overweight ${ }^{2}$. The Food and Nutrition Monitoring System (FNMS/SISVAN) describes the prevalence of overweight in $15 \%$ of the population under six years of age, and there is evidence that the evolution of the median weight exceeds WHO standards, tending to overweight in a comparison between the following surveys: Familial Income National Study (FINS/ENDEF), Health and Nutrition National Study (HNNS/PNSN) and Familial Incomes Research (FIR/POF). The same is observed in other national studies such as Nutri-Brazil Childhood ${ }^{1}$.

Excess weight has a strong correlation with the development of metabolic syndrome and other chronic diseases, increasing the risk of orthopaedic, pulmonary,

\footnotetext{
1 Instituto PENSI/Hospital Infantil Sabará/Fundação José Luiz Egídio Setúbal.

2 Prof. Livre Docente em Pediatria - Instituto da Criança da Faculdade de Medicina da Universidade de São Paulo e Departamento de Pediatria da Faculdade de Medicina da Universidade de São Paulo.

3 Laboratório de Delineamento de estudos e escrita científica da Faculdade de Medicina do ABC.

4. Professor titular do Departamento de Saúde Materno Infantil, FSP - USP.
}

Corresponding author: Rubens Feferbaum. E-mail: rfeferbaum@uol.com.br

Suggested citation: Machado RHV, Ferferbam R, Leone C. Fruit intake and obesity. Fruit and vegetables consumption and obesity in Brazil. J Hum Growth Dev. 26(2): 243-252. Doi: http://dx.doi.org/10.7322/jhgd.119293.

Manuscript submitted: Jun 22 2016, accepted for publication Jul 142016. 
gastrointestinal, neuroendocrine disorders, and psychosocial consequences. When this condition develops in childhood there is a high possibility of it continuing in adult life ${ }^{1}$; and obese parents raise children prone to the same condition, given the influence and interference of behavioural epigenetics, that modulates foetal metabolism from pregnancy ${ }^{1,3}$. Such relationships demonstrate the cyclical relationship of overweight and suggest the urgency and specificity of therapeutic and preventive actions ${ }^{4}$.

Among the protective factors for overweight, the consumption of fruit and vegetables (FV), of low calorie and low fat foods, and a high percentage of fibres, contributes to increased satiety and to reducing the total intake of food ${ }^{5}$. The WHO recommends a minimum consumption of FV of $400 \mathrm{~g} /$ day, equivalent to 5 daily servings of those foods for all age groups; national references endorse the same practices, for example, the most recent dietary guidelines of the Brazilian Ministry of Health for the Brazilian population, which recommend a minimum daily intake of 3 servings of fruit and 3 of vegetables, and the Brazilian Society of Paediatrics (BSP/SPB), which promotes the consumption of more than five daily servings for children and adolescents as a way to prevent obesity ${ }^{4,6,7,8}$. Consumption data, however, show insufficient intake worldwide in all age groups. The POF ${ }^{9}$ reported a consumption below the recommendations in $90 \%$ of the population and there is evidence that most people do not even know the recommendations for these foods ${ }^{6}$.

In view of this situation, the Brazilian Ministry of Health coordinated the preparation of the 'Actions and Strategies Plan for Confronting Chronic Non-communicable Diseases in Brazil, 2011-2022', with the suggestion of goals and actions for the year 2022 that address modifiable risk factors for obesity. It is proposed to increase the prevalence of the recommended consumption of FV by $10 \%{ }^{10}$. Therefore, the goal is to map the situation of fruit consumption in Brazil in the last decade during the life cycle and to analyze the association of fruit consumption and the prevalence of overweight.

\section{METHODS}

This is a literature review of empirical bases, such as BVS (Scielo/Lilacs/Bireme/Cochrane), in the period 2005 to 2015 . The search terms were used individually or combined, according to Boolean operators 'and', 'or': "Fruit", "consumption", “obesity", “overweight”, "Brazil”, "pregnancy", "childhood”, "adolescence”, "seniors", "adults".

The inclusion criteria of this study guided the selection of studies that were intended to present the prevalence of fruit consumption alone or in association with the consumption of vegetables (in grams or portions/day, considering only fruit in natural form or natural fruit juices, excluding sugary drinks and artificial juices), and to correlate consumption data with the body mass index (BMI). The appropriate consumption of FV followed the recommendations of $400 \mathrm{~g} /$ day or a frequency of 5 servings/day (3 servings/day for fruit alone). Regarding the classification of overweight, selected articles use benchmarks according to each age group and development cycle. Only transverse character field work or cohorts studied in Brazil with the populations referred to were selected; revisions or works whose sample was representative or estimated by sample calculation were excluded.

The process for the selection of studies took place according to the following steps: 1) Reading the titles and abstracts of articles found; 2) Exclusion of foreign works and duplicates; 3) Exclusion of studies and designs with inadequate sample size; 4) Exclusion of studies not compatible with goals and 5) Reading articles entirely. 21 works were selected in the English and Portuguese language, characterized according to the desing and population group: maternal $(n=3$, cross-sectional cohort $n=3)$, transverse ( $\mathrm{n}=5, \mathrm{n}=1$ cohort), adults and elderly $(\mathrm{n}=8$, cross-sectional cohort $\mathrm{n}=1$ ), and 3 official documents. The process followed is described in Fluxogram 1.

\section{Fluxogram 1. Flow of articles}

Red titles and abstract of articles found $-n=779$

\section{Exclusion and foreign works and}

$$
\mathrm{n}=174
$$

Exclusion and study design, year of publication and simple size incompatible with inclusion criteria

$$
n=52
$$

Research focus and exclusion incompatible with objectives

$$
n=24
$$

Read full articles

$$
n=2
$$

"Fruits" and "consumption" and ("obesity" or "overwigth") and ("pregnancy" or pregnancy") - N = 70

"Fruits" and "consumption" and ("obesity" or "overwigth") and ("child" or "chidwood") - N = 299

"Fruits" and "consumption" and ("obesity" or "overwigth") and ("adolescence" ou "adolescent") - N = 256

"Fruits" and "consumption" and ("obesity" or "overwigth") and ("adult") - N = 98

"Fruits" and "consumption" and ("obesity" or "overwigth") and ("ederly") - N = 56

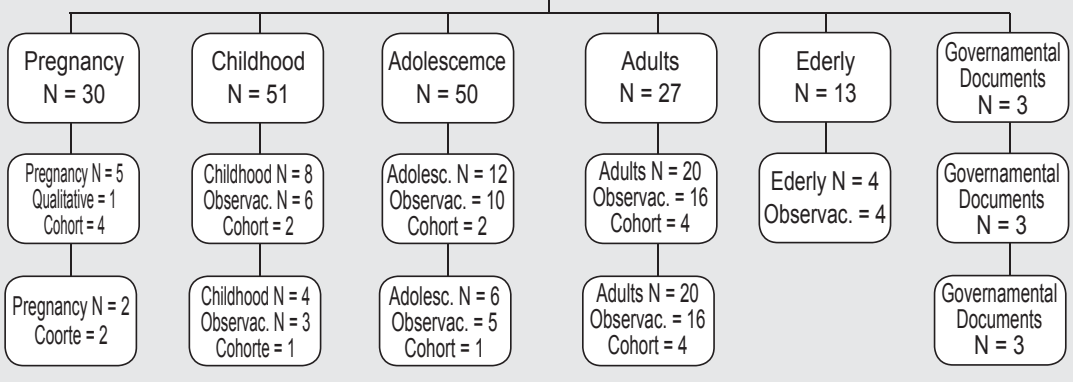


Table 1: National studies on the prevalence of consumption of fruits according to development cycle.

\begin{tabular}{|c|c|c|c|c|c|}
\hline $\begin{array}{c}\text { Reference } \\
\text { Maternal and }\end{array}$ & child Objective & Study design & Population & Variable and metods used & Results/Innovation \\
\hline $\begin{array}{l}\text { Santana } \\
\text { AC (2013) }\end{array}$ & $\begin{array}{l}\text { To evaluate the influence } \\
\text { of food intake on } \\
\text { gestational weight gain } \\
\text { from the } 2^{\text {nd }} \text { quarter } \\
\text { forward. }\end{array}$ & Cohort & $\begin{array}{l}195 \text { healthy preg- } \\
\text { nant women, } \\
\text { over } 19 \text { years } \\
\text { old in } \\
\text { São Paulo, Brazil }\end{array}$ & $\begin{array}{l}\text { Weight gain (BMI/gestational age } \\
\text { (Atalah curve) } \\
\text { Food intake frequency question- } \\
\text { naire and } 224 \mathrm{~h} \text { recall per quarter } \\
\text { FV consumption in grams (g) }\end{array}$ & $\begin{array}{l}\text { Average consumption per quarter ( } 1 \mathrm{st}- \\
\pm 350 \mathrm{~g} ; 2 \mathrm{nd}-350 \mathrm{~g}, 3 \mathrm{rd}-313 \mathrm{~g} \text { ) below } \\
\text { the recommendations. FV consumption } \\
\text { was not associated with weight gain in } \\
\text { pregnant women. } \\
\text { Average fibre intake }( \pm 16 \mathrm{~g} \text { in all quar- } \\
\text { ters) below the recommendations. Fibre } \\
\text { consumption was associated with wei- } \\
\text { ght gain in pregnant women }(P=0.05) \text {. }\end{array}$ \\
\hline $\begin{array}{l}\text { Ciochetto } \\
\text { CR (2012) }\end{array}$ & $\begin{array}{l}\text { To describe the } \\
\text { frequency of } \\
\text { consumption of fruits } \\
\text { and vegetables and their } \\
\text { association with socio- } \\
\text { demographic variables } \\
\text { and nutritional condition. }\end{array}$ & Transversal & $\begin{array}{l}356 \text { school chil- } \\
\text { dren in the public } \\
\text { school system } \\
\text { in Pelotas, Rio } \\
\text { Grande do Sul, } \\
\text { Brazil }\end{array}$ & $\begin{array}{l}\text { BMI/Age - WHO (2007) } \\
\text { Food Intake Questionnaire - } \\
\text { SISVAN. } \\
\text { Fruit consumption categorized } \\
\text { as frequent ( }>5 \text { days/week) or } \\
\text { infrequent. }\end{array}$ & $\begin{array}{l}12 \% \text { prevalence of no consumption in } \\
\text { the period } \\
42 \% \text { prevalence of regular consumption } \\
\text { of fruit } \\
\text { There was no association between BMI } \\
\text { and regular consumption of fruit. }\end{array}$ \\
\hline $\begin{array}{l}\text { Castro } \\
\text { MBT (2006 }\end{array}$ & $\begin{array}{l}\text { Describe food intake } \\
\text { of cohort of women } \\
\text { during pregnancy and } \\
\text { postpartum, comparing } \\
\text { the two periods. }\end{array}$ & Cohort & $\begin{array}{l}276 \text { healthy wo- } \\
\text { men }>15 \text { years } \\
\text { old; } \\
\text { Rio de Janeiro, } \\
\text { Brazil }\end{array}$ & $\begin{array}{l}\text { Fruit Consumption (pcs./day) du- } \\
\text { ring the 3rd trimester of pregnancy } \\
\text { and } 30 \text { days postpartum } \\
\text { Method: Food Consumption Fre- } \\
\text { quency Questionnaire. }\end{array}$ & $\begin{array}{l}\text { Average consumption during pregnancy } \\
(4 \mathrm{pcs} / \text { day) } \\
\text { Average postpartum consumption ( } 1.94 \\
\text { units/day; } P<0.0001) \\
\text { Decrease in consumption of fruits affec- } \\
\text { ted the intake of vitamin } C(p<0.0001)\end{array}$ \\
\hline $\begin{array}{l}\text { Cagliari } \\
\text { MPP (2009) }\end{array}$ & $\begin{array}{l}\text { Evaluate frequency } \\
\text { of food intake, } \\
\text { anthropometry, and } \\
\text { association with the } \\
\text { occurrence of morbidity } \\
\text { in the three previous } \\
\text { months. }\end{array}$ & Transversal & $\begin{array}{l}112 \text { children } \\
\text { between } 2 \text { and } 5 \\
\text { years old. } \\
\text { Paraiba, Brazil }\end{array}$ & $\begin{array}{l}\text { usedWeight and height - criteria } \\
\text { by NCHS (not used in this } \\
\text { analysis) } \\
\text { Frequency consumption of fruit } \\
\text { (times/week) - Food Intake Fre- } \\
\text { quency Questionnaire }\end{array}$ & $\begin{array}{l}25 \% \text { fruit intake between } 1-4 \text { times/ } \\
\text { week } \\
75 \% \text { daily fruit intake - no estimated } \\
\text { portions } \\
\text { Positive association between daily } \\
\text { fruit intake and reduction in diarrhoea } \\
\text { frequency }(p=0.039) \text {. }\end{array}$ \\
\hline $\begin{array}{l}\text { Grillo LP } \\
\text { (2005) }\end{array}$ & $\begin{array}{l}\text { Check the nutrition of } \\
\text { schoolchildren between } \\
5-12 \text { years of age in low- } \\
\text { income families. }\end{array}$ & Transversal & $\begin{array}{l}579 \text { children } \\
\text { between } 5-10 \\
\text { years old; } \\
\text { Florianópolis, } \\
\text { Santa Catarina, } \\
\text { Brazil }\end{array}$ & $\begin{array}{l}\text { Weight and height - Criteria } \\
\text { according to NCHS (not used in } \\
\text { this analysis) } \\
\text { Frequency consumption of fruit } \\
\text { (times/week) - Food Frequency } \\
\text { Questionnaire }\end{array}$ & $\begin{array}{l}\text { Inadequate consumption }-48 \% \text { of the } \\
\text { children } \\
\text { The study did not estimate portions or } \\
\text { describe the consumption frequency of } \\
\text { subjects. }\end{array}$ \\
\hline $\begin{array}{l}\text { Rauber } \\
\text { F (2014) }\end{array}$ & $\begin{array}{l}\text { Describe food intake } \\
\text { To evaluate the effect } \\
\text { of an intervention } \\
\text { with the mothers } \\
\text { of schoolchildren } \\
\text { throughout childhood } \\
\text { and usual food intake }\end{array}$ & Cohort & $\begin{array}{l}345 \text { children } \\
\text { between } 3-8 \\
\text { years old } \\
\text { Rio Grande do } \\
\text { Sul, Brazil }\end{array}$ & $\begin{array}{l}\text { Children divided between interven- } \\
\text { tion and control group, assessed } \\
\text { at 3-4 years and reevaluated 7-8 } \\
\text { years; } \\
24 \mathrm{~h} \text { recall } 24 \text { held } 2 \text { times + Diet } \\
\text { Quality Score } \\
\text { Fruit estimated in portions grams/ } \\
\text { day }\end{array}$ & $\begin{array}{l}\text { The impact of intervention with mothers } \\
\text { was positive to } 3-4 \text { years of age, but } \\
\text { lost in the } 2 \text { nd revaluation; } \\
\text { Average consumption of fruits }<1 \text { ser- } \\
\text { ving daily in both groups } \\
\text { Reduced consumption of fruit over the } \\
\text { years (adequacy fell } 13 \% \text { in the interven- } \\
\text { tion group - } 16 \% \text { to } 3 \% \text { and } 7 \% \text { in the } \\
\text { control group }-10 \% \text { to }<3 \% \text { ( }<0.01 \text { ). }\end{array}$ \\
\hline
\end{tabular}

Adolecence

$\begin{array}{lll}\text { Monticelli } & \begin{array}{l}\text { To describe the } \\ \text { frequency of }\end{array} & \text { Transversal } \\ \text { consumption of fruits/ } & \\ \text { juices and vegetables } \\ \text { and compare them to } \\ \text { the recommendations of } \\ \text { the "10 steps to healthy } \\ \text { eating" }\end{array}$

420 adolescents both genders Public system schools $>10$ years São Paulo, Brazil $10-12$ years old Both genders Curitiba, Parana, Brazil
Questionnaire with socioeconomic Inadequate consumption of fruits/juices and personal information LV consumption was considered appropriate frequency ( $\geq 3$ times/ day)

and vegetables $(71 \%)$

Only $3.5 \%$ of them had adequate consumption of the two groups of food The consumption of fruit/juice was not associated with variables.

For vegetables there was inadequate consumption of association with the largest age group (14-19 years) (OR age $14-19$ vs $11-12$ age: 0.29 , p: 0.04 ).

Questionnaire with socioeconomic Low consumption of fruits and vegetaand personal information Frequency consumption of fruit (servings/day) - Food Frequency Questionnaire

Weight and height - Criteria according to NCHS (not used in this analysis) bles - an average of 2.3 servings/day Approximately $28.0 \%$ of the adolescents did not meet the minimum recommendation of consumption of three servings of fruits and three servings of vegetables a day.

About $73 \%$ of the sample does not consume adequate servings of fruits/day

There was no relationship between adequate dietary intake and overweight.
Dumith SC (2012)
To investigate risk factors for NCDs in adolescents.
Cohort

3990 adolescents 14-15 years Sub sample: Cohort Pelotas (1993).
Clustering of risk factors: fruit con- $72 \%$ of the sample did not consume sumption (frequency of servings/ fruit daily

day), smoking, alcohol consump- The prevalence of inadequate intake tion and physical activity
The prevalence of inadequate in
was higher in males $(p<0.03)$ In women, low fruit consumption was associated with lower levels of physical activity $(p>0.03)$ 


\begin{tabular}{|c|c|c|c|c|c|}
\hline Reference & Objective & & Population & Variable and metodos utilizados & Resultados/Inovação \\
\hline $\begin{array}{l}\text { Mello MVFA } \\
(2013)\end{array}$ & $\begin{array}{l}\text { Identifying obesity for } \\
\text { risk factors (diabetes } \\
\text { plus obesity) in primary } \\
\text { students in the Brazilian } \\
\text { Amazon. }\end{array}$ & $\begin{array}{l}\text { Mondini } \\
\text { L (2010) }\end{array}$ & $\begin{array}{l}1218 \text { adolescents } \\
\text { Both genders } \\
\text { Amazônia, Brazil }\end{array}$ & $\begin{array}{l}\text { Questionnaire "How's your food } \\
\text { intake?" The Ministry of Health } \\
\text { of Brazil } \\
\text { Questionnaire with sociodemogra- } \\
\text { phic information, clinical referred } \\
\text { anthropometric (BMI WHO 2007) } \\
\text { and food intake (consumption of } \\
\text { fruit servings/day). }\end{array}$ & $\begin{array}{l}\text { Frequency of consumption of fruit } \geq 3 \\
\text { servings/day in only } 35 \% \text { of the sample } \\
28 \% \text { prevalence of overweight } \\
\text { The study did not compare the BMI with } \\
\text { the consumption of fruit }\end{array}$ \\
\hline $\begin{array}{l}\text { Muniz LC } \\
(2013\end{array}$ & $\begin{array}{l}\text { To assess the } \\
\text { prevalence and factors } \\
\text { associated with daily } \\
\text { consumption of fruits and } \\
\text { vegetables (FV) among } \\
\text { adolescents from public } \\
\text { schools. }\end{array}$ & $\begin{array}{l}\text { Viebig RF } \\
\text { (2009)Study }\end{array}$ & $\begin{array}{l}649 \text { young people } \\
15-20 \text { years } \\
\text { Both genders } \\
\text { Pernambuco, } \\
\text { Brazil }\end{array}$ & $\begin{array}{l}\text { Questionnaire: Daily consumption } \\
\text { of fruits, daily consumption of } \\
\text { vegetables, and daily consumption } \\
\text { of both food (times/day) } \\
\text { Considered positive outcomes } \\
\text { that presented consumption rate } \geq \\
\text { once a day. }\end{array}$ & $\begin{array}{l}\text { About } 10 \%(95 \% \mathrm{Cl}: 5.5,14.2) \text { of the } \\
\text { teens reported never consuming fruit. } \\
\text { There was no statistically significant } \\
\text { difference between the sexes for the } \\
\text { consumption of fruit. } \\
\text { Daily fruit consumption: prevalence } \\
\text { of } 32.9 \%(95 \% \mathrm{Cl}: 28.3,37.6) \text {. Among } \\
\text { adolescents who reported consuming } \\
\text { fruit daily, the majority }(52.1 \%)(95 \% \mathrm{Cl} \text { : } \\
41.0 ; 63.1) \text { consumes only once a day. } \\
\text { There was no significant association } \\
\text { with BMI }\end{array}$ \\
\hline $\begin{array}{l}\text { Rieth MA } \\
(2012)\end{array}$ & $\begin{array}{l}\text { Investigate fruit and } \\
\text { vegetable intake in } \\
\text { adolescents and its } \\
\text { relationship with gender, } \\
\text { age and education. }\end{array}$ & $\begin{array}{l}\text { design } \\
\text { Transversal }\end{array}$ & $\begin{array}{l}568 \text { adolescents } \\
12-19 \text { years } \\
\text { Both genders }\end{array}$ & $\begin{array}{l}\text { Weight and height - according to } \\
\text { WHO criteria (2007) } \\
\text { Weight and height - Criteria accor- } \\
\text { ding to WHO (2007) } \\
\text { Questionnaire with socioeconomic }\end{array}$ & $\begin{array}{l}\text { Prevalence of overweight in } 23 \% \text { of the } \\
\text { sample } \\
\text { Consumption of } 5 \text { servings/day of } \mathrm{FV} \text { in } \\
\text { only } 23 \% \text { of the sample } \\
\text { Average consumption of } 2 \text { servings of } \\
\text { fruits/day } \\
\text { The consumption was not associated } \\
\text { with gender. }\end{array}$ \\
\hline
\end{tabular}

Adults and Elderly

\begin{tabular}{|c|c|c|c|c|}
\hline $\begin{array}{l}\text { Amado } \\
\text { TCF (2007) }\end{array}$ & $\begin{array}{l}\text { Identify food, nutrition } \\
\text { and health aspects in } \\
\text { elderly women. }\end{array}$ & Transversal & $\begin{array}{l}106 \text { women> } 60 \\
\text { years } \\
\text { Care Center for } \\
\text { the Elderly - NAI } \\
\text { Universidade } \\
\text { Federal de Per- } \\
\text { nambuco, Brazil }\end{array}$ & $\begin{array}{l}\text { Frequency consumption of fruit } \\
\text { (times/week) - Food Frequency } \\
\text { Questionnaire }\end{array}$ \\
\hline $\begin{array}{l}\text { Sartorelli } \\
\text { DS (2008) }\end{array}$ & $\begin{array}{l}\text { Identifying the } \\
\text { relationship between the } \\
\text { consumption of fruits and } \\
\text { weight loss. }\end{array}$ & Transversal & $\begin{array}{l}80 \text { adults with } \\
\text { overweight, } \\
\text { Ribeirão Preto, } \\
\text { São Paulo, Brazil }\end{array}$ & $\begin{array}{l}\text { Nutritional counselling program for } \\
6 \text { months; } \\
\text { Frequency consumption of fruit } \\
\text { (times/week) - Food Frequency } \\
\text { Questionnaire }\end{array}$ \\
\hline
\end{tabular}

Perozzo

G (2008)

To investigate the association of dietary patterns found in adult women with general and abdominal obesity.

Iser Describe the key risk

BPM (2012) and protective factors for chronic diseases telephone survey data from 2010 - Vigitel.

Jaime To estimate the PC (2009) frequency of consumption of fruits and vegetables and factors associated with telephone survey data from 2006 - Vigitel.

Palma Identify association RFM (2009) between sociodemographic anthropometric, presence of morbidities and lifestyle with fruit and vegetable intake.
Transversal 1026 women Frequency consumption of fruit between 20-60 years old São Leopoldo, Rio Grande do Sul, Brazil

Cohort

54.339 people over 18 years Capitals of Brazil and the Federal District.

54.369 people over 18 years Capitals of Brazil and the Federal District.

Transversal

581 healthy adults over 20 years of Japanese-Brazilian origin; Bauru, São Paulo, Brazil (times/week) - Food Frequency Questionnaire Low consumption of fruit was considered the lower-fifths of the sample.

Telephone interviews a day, on five or more days of the week.

Telephone interviews week regular: $>5$ days of the week.

fruit consumption evaluated by three $24 \mathrm{~h}$ recalls.

Analysis by adjusted logistic regression
Daily fruit consumption in $66 \%$ of the population

The study did not estimate portions or describe the consumption frequency of subjects.

The consumption of fruit was not associated with hypertension rates.

Association between consumption of fruits and weight loss after 6 months of follow-up $(\beta 1[95 \% \mathrm{Cl}]=-0.00290$ $[-0005,-0001])$.

Increase of $100 \mathrm{~g} /$ day consumption of fruit represent weight loss of $300 \mathrm{~g}$, adjusted for gender, age, physical activity and energy intake $(p<0.05)$.

Low consumption of fruit was associated with increased risk of obesity, after correction for confounding factors (PR = Obesity criteria according to BMI $2.18 ; 95 \% \mathrm{Cl}: 1: 35$ to $3: 53 ; p=0.001$ ).

The prevalence rates were stratified by gender, age and education. Fruit and vegetables classified as appropriate: five or more servings The prevalence rates were strati- regular fruit (44.1\%) and vegetable fied by gender, age and education. (43.8\%) consumption, while $23.9 \%$ Fruit and vegetables classified as reported regular consumption of fruit appropriate: five or more servings and vegetables together;

a day, on five or more days of the Adequate consumption was reported by

$7.3 \%$ of respondents.

Fruit and vegetables classified as Fruit and vegetables varies among the Fis wher among women and increased with age and education.
Increased number of daily meals was associated with increased odds [OR $(95 \% \mathrm{Cl})]$ : $[1.31(1.05,1.63)]$ of adequate consumption of fruits and vegetables. Increased trend of adequate consumption of fruits and vegetables among older individuals.

prevalence of $40 \%(n=233)$ consumption of $>400 \mathrm{~g} /$ day for FV. 


\begin{tabular}{|c|c|c|c|c|c|}
\hline Reference & Objective & Study design & Population & Variable and metods used & Results/Innovation \\
\hline $\begin{array}{l}\text { Mondini } \\
\text { L (2010) }\end{array}$ & $\begin{array}{l}\text { Evaluate the } \\
\text { consumption of fruits and } \\
\text { vegetables by adults and } \\
\text { identify } \\
\text { sociodemographic } \\
\text { and lifestyle variables } \\
\text { associated with the } \\
\text { consumption of these } \\
\text { food. }\end{array}$ & Transversal & $\begin{array}{l}930 \text { participants> } \\
30 \text { years } \\
\text { Ribeirão Preto, } \\
\text { São Paulo, Brazil. }\end{array}$ & $\begin{array}{l}\text { Consumption of fruits and vege- } \\
\text { tables through semi quantitative } \\
\text { frequency questionnaire } \\
\text { Results adjusted for age, marital } \\
\text { status, education, family income, } \\
\text { nutritional condition, smoking and } \\
\text { physical activity. }\end{array}$ & $\begin{array}{l}\text { Only } 24 \% \text { of men and } 38 \% \text { of women } \\
\text { met the minimum recommendation of } \\
\text { fruit and vegetables; } \\
\text { Women with higher education and men } \\
\text { who lived with partner consumed more } \\
\text { fruits and vegetables than others. }\end{array}$ \\
\hline $\begin{array}{l}\text { Ramalho } \\
\text { AA (2012) }\end{array}$ & $\begin{array}{l}\text { To assess the } \\
\text { prevalence and factors } \\
\text { associated with regular } \\
\text { consumption of fruits } \\
\text { and vegetables in } \\
\text { academics. }\end{array}$ & Transversal & $\begin{array}{l}863 \text { university } \\
\text { students over } 18 \\
\text { years; } \\
\text { Acre, Brazil. }\end{array}$ & $\begin{array}{l}\text { Demographic and socioeconomic } \\
\text { variables: gender, age, economic } \\
\text { status, employment status, marital } \\
\text { status, number of children. } \\
\text { Frequency consumption of fruit } \\
\text { (times/week) - Food Frequency } \\
\text { Questionnaire } \\
\text { Fruits categorized into regular } \\
\text { (5 or more days a week) and } \\
\text { irregular (4 or fewer days a week) } \\
\text { consumption. }\end{array}$ & $\begin{array}{l}\text { General prevalence of regular con- } \\
\text { sumption of fruits and vegetables was } \\
14.8 \% \text { (without difference between } \\
\text { gender) } \\
\text { Regular consumption of fruits and vege- } \\
\text { tables increased with age }(p=0.004) \text {. }\end{array}$ \\
\hline $\begin{array}{l}\text { Viebig RF } \\
(2009)\end{array}$ & $\begin{array}{l}\text { Estimate the } \\
\text { socioeconomic and } \\
\text { sociodemographic } \\
\text { factors associated } \\
\text { with the daily intake of } \\
\text { five servings of fruits } \\
\text { and vegetables for the } \\
\text { elderly. }\end{array}$ & Transversal & $\begin{array}{l}2,066 \text { elderly ( } \geq 60 \\
\text { years) of low- } \\
\text {-income } \\
\text { São Paulo, Brazil }\end{array}$ & $\begin{array}{l}\text { Frequency consumption of fruit } \\
\text { (times/week) - Food Frequency } \\
\text { Questionnaire }\end{array}$ & $\begin{array}{l}\text { About a third of the elderly ( } n=723 \text {; } \\
35,0 \% \text { ) than daily consume any kind of } \\
\text { fruit or vegetable and } 19.8 \% \text { reported } \\
\text { daily consumption of five or more ser- } \\
\text { vings of fruits and vegetables. } \\
\text { This consumption was positively asso- } \\
\text { ciated with income and education. }\end{array}$ \\
\hline
\end{tabular}

\section{RESULTS}

In general, insufficient consumption of fruits in Brazil is evidenced in all the studies presented and in all cycles of development. The main results of the selected studies, with their respective fruit consumption data, are described in Table 1.

\section{DISCUSSION}

\section{Child population}

There are a few studies on FV consumption during gestation and lactation in Brazil. In the study of Santa$\mathrm{na}^{5}$, with 195 pregnant adult women, there was an average consumption of about $\pm 340 \mathrm{~g} /$ day, below the recommendations in all quarters. Similar results were found in the literature cited in this study, with average consumption of $335 \mathrm{~g} /$ day for pregnant women. However, the low consumption was not associated with weight gain in the women, only the total fibre consumption in the diet (mean 16 $\mathrm{g}$ /day), which was also classified as low. A previous study conducted by Castro et al. ${ }^{11}$ shows that, during pregnancy, the number of servings of fruits - specifically -consumed by 276 pregnant women in Rio de Janeiro Brazil, was satisfactory (about 4 servings/day), but that, however, was reduced by half ( 1.94 portions, $\mathrm{p}<0.0001$ ) when compared to the consumption in the postpartum period.

A reduction in the consumption of fruit during the period of pregnancy/lactation can contribute to a decrease in the consumption of micronutrients and fibre, important for foetal and maternal development. This factor was verified in the study of Castro $^{11}$, in which the reduction in the consumption of fruit in the postpartum period directly contributed to a decrease in the intake of vitamin $\mathrm{C}$, for example. In addition, Baião et al. ${ }^{12}$, in a qualitative study with 26 pregnant women and recent mothers of low socioeconomic level in Rio de Janeiro, Brazil, analyzed dietary practices in pregnancy from the women's perspective, which classified fruits as basic items in the diet that were expendable if the economic situation was difficult, reinforcing the need for educational activities in this segment of the population.

In the study of Santana ${ }^{5}$, although there is no correlation between weight gain in pregnant women and the consumption of $\mathrm{FV}$, there was an inverse relationship between total fibre consumption and weight gain. Various works cited by this study show a correlation between inadequate consumption of fibre and a $25 \%$ increased risk of developing obesity in the postpartum period.

FV consumption in childhood also remains low. Cagliari et al. ${ }^{13}$, in their study of 112 preschoolers in Paraiba, Brazil, reported the prevalence of daily consumption of fruits in $75 \%$, without determining, however, the servings. Despite not being able to estimate the consumption of these children, it should be noted that $25 \%$ of this population did not even consume 1 portion of fruit daily. Grillo et al. (2005) $)^{14}$, studied 579 children in Florianopolis, to estimate just the adequacy/inadequacy of consumption based on the recommendations, and found a prevalence of inadequate consumption of $48 \%$ of those evaluated. Data from a cohort of 345 children aged between 3 and 8 years in southern Brazil ${ }^{15}$, showed the average fruit consumption to be less than 1 portion daily. The children were evaluated between 3 and 4 years, and again between 7 and 8 , and only $16 \%$ and $10.5 \%$ of children between 3 and 4 years, and $2.5 \%$ and $3 \%$ of children between 7 and 8 in the intervention and control groups, respectively, reached the recommendations for the fruit consumption group $(\mathrm{p}<$ 0.01). In cross-sectional work in Pelotas, southern Brazil ${ }^{7}$ with 356 public schoolchildren, the prevalence of frequent consumption of fruit (when the foods were consumed in at 
least five of the seven days preceding the interview) were $42.1 \%$, although this frequent consumption was associated with a lower school age group $(\mathrm{p}=0.02)$. There was no positive association, however, with the condition of overweight children. In addition, $12 \%$ onsumed fruits in the 7 days evaluated prior to the interview. The Nutri-Childhood Brazil study ${ }^{16}$, a multicentre study held in 12 Brazilian cities with 3,100 children aged between 2 and 6 years, recorded the fresh fruit contribution to the intake of total fibre and vitamin $\mathrm{C}$, for example, less than $5 \%$, and $80 \%$ inadequacy of usual fibre consumption. The cohort of Rauber et al..$^{15}$ - mentioned previously - clearly shows how the prevalence of adequate consumption is reduced over time (from $16 \%$ to $3 \%$ ). Even the positive effect of the nutritional advice given to their mothers during the intervention period was lost by the time of the re-evaluation at 7-8 years. This development is also described by other works; and may reflect the autonomy of children about food choices over time, combined with environments where an unhealthy food supply can take the place of fruit.

In relation to studies that found no association between fruit consumption and excess weight ${ }^{7}$, it is worth mentioning that such results may be due to limitations in the statistical variables used and sample size.

\section{Adolescence}

Several studies have shown low consumption of FV at between 15 and 24 years, with a lower consumption frequency of 4 times a week for around $50 \%$. Prevalence under $30 \%$ has been reported in studies with teenagers independent of age and methods for evaluating consumption $7,9,17,18,19$. Two studies that evaluated 341 teenagers between 11 and 14 years in public schools in Curitiba ${ }^{9}$ and 431 adolescents with an average of 12 years of age in public school of Piracicaba (SP) ${ }^{20}$, observed a prevalence of $29 \%$ and $28 \%$ of fruit consumption of more than 3 servings per day, respectively. The traditional cohort of Pellets ${ }^{21}$ showed that only $28.2 \%$ of 3,990 adolescents evaluated (between 14 and 15 years) consumed at least 1 serving of fruit daily. Mello et al. ${ }^{22}$ verified, with 1,218 adolescents with an average of 12 years in Amapá, northern Brazil, a 35\% prevalence of adequate consumption of fruit. A study conducted with 624 adolescents between 14 and 19 years in public schools in Pernambuco ${ }^{23}$ showed a prevalence of just $7 \%$. Analysis of $\mathrm{POF}^{24}$ demonstrates that the banana was the only fruit included in a list of 20 most commonly eaten foods among teenagers, with a $12 \%$ prevalence of daily consumption (last position on the list).

The study conducted in Piracicaba ${ }^{20}$ found no association between fruit consumption and overweight, but analyses were carried out using criteria of obesity prior to the current WHO recommendations. The SOFT study ${ }^{19}$, performed with 578 teenagers between 12 and 19 years old of Rio Grande do Sul also found no association between BMI and isolated fruit consumption (the average consumption of the population was 2 daily servings, with $25 \%$ prevalence of adequate consumption). However, the authors point out that most studies that present an inverse relationship between fruit consumption and BMI and adolescent adiposity have samples of larger size and with quantitative ratings (g/day). This method is not used by most studies conducted in Brazil.

\section{Adults and elderly}

The Surveillance of Risk and Protective Factors for Chronic diseases (Vigitel) is a cross-sectional study representative of the adult and older population, with about 54,000 telephone interviews in 27 Brazilian state capitals annually, and is used as a monitoring tool by the Brazilian Ministry of Health about the goals proposed for the year $2022^{10}$. Comparing the data available between 2006 and $2014^{25.26,21}$ as shown in Figure 1 , there was an increase in the prevalence of adequate consumption of fruits and vegetables, both in the general population and when stratified by gender, with women maintaining a higher consumption pattern over time. In Vigitel survey ${ }^{27}$, the major frequencies were found

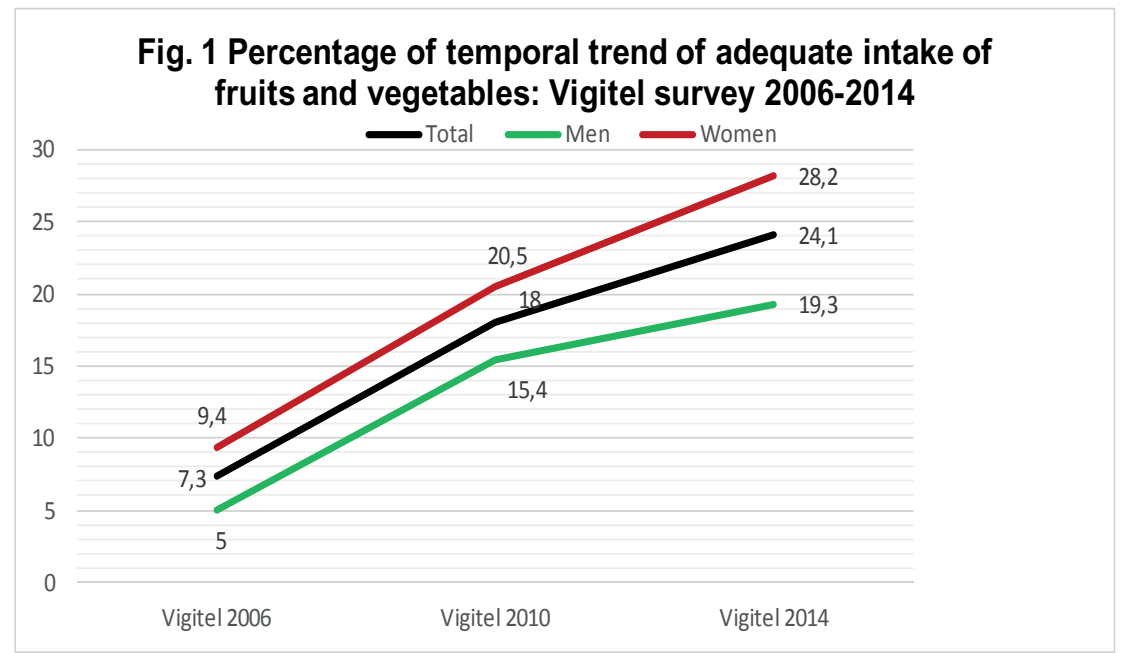

Figure 1: Model of influential factors in consumption habits across lifespan. 
among men, in Vitória (23.5\%), Florianópolis (23.4\%) and Porto Alegre (23.4\%) and, among women, in the Federal District (36.6\%), Florianópolis $(35.6 \%)$ and Belo Horizonte (34.8\%). The lowest frequencies in men occurred in Belém (13.4\%), Rio Branco (13.7\%) and Manaus (14.0\%) and, in female, in Rio Branco (17.4\%), Belém (19.3\%) and Maceió (19.8\%). Such frequencies of consumption showed a tendency to increase with age and schooling in all groups. It can be said, therefore, that the consumption trend for FV among individuals older than 18 years increased by $20 \%$ between 2010 and 2014, reaching the goal proposed by the Brazilian Ministry of Health $^{10}$. In comparison to data from the year 2006, adequate consumption of fruits and vegetables tripled, although this still represents a minority of the population. Several other studies with adult populations describe a similar prevalence of fruit consumption, as well as its relation with age and $\operatorname{sex}^{28,29.30}$.

Specifically in relation to data on the elderly, evolution follows similarly: in $2006^{25}$, the prevalence of adequate consumption was $12 \%$ in this age group, increasing to $22 \%$ in $2010^{26}$ (25\% in women and $17 \%$ in men) and $26.8 \%$ in $2013^{27}(29.4 \%$ and $22.7 \%$ in women and men respectively). POF data 2008/200924 corroborate these findings: banana was the only fruit included in the foods commonly consumed by the elderly and only this age group included a second fruit. In the fourth quartile, the prevalence of daily consumption of bananas was only $20 \%$ for seniors and $15 \%$ for adults.

Another study conducted with a sample of 106 elderly in Recife ${ }^{31}$, showed $34 \%$ with infrequent fruit consumption (considered not daily), but not evaluated, and of $66 \%$ of the population that consumed fruits daily, there was an intake in sufficient quantities to achieve the recommendations. No comparisons were carried out with the
BMI of elderly people. Viebig et al. (2009) 32 also found similar results for intake among 2,066 elderly residents in Sao Paulo: only 19.8\% reported daily consumption of five or more servings of FV. The study also cites other literature results, with reports of adequate consumption in about $20 \%$ of the elderly population only in the city of São Paulo. It is mportant to note that of the elderly people who ate fruits and vegetables daily, $45.2 \%$ did not reach the quantitative recommendations for these foods.

With regard to the relationship of consumption of fruits with beingoverweight, Staff et al. ${ }^{33}$ found an association between fruit consumption and weight loss in 80 adults $(\beta 1[95 \% \mathrm{CI}]=-0.00290[-,-0.0010 .005])$ after 6 months of nutritional monitoring, concluding that an increase of $100 \mathrm{~g} /$ day in fruit consumption represents $300 \mathrm{~g}$ weight loss after the intervention period adjusted for sex, age, physical activity and energy intake $(p<0.05)$. A research study carried out with 1,026 adult women from southern Brazil ${ }^{34}$ found that low consumption of fruit was associated with increased risk of obesity $(\mathrm{RR}=2.18 ; 95 \%$ CI: $1.35-3.53 ; \mathrm{p}=0.001$ ). Additionally, a study ${ }^{6}$ of 636 adults demonstrated that adequate consumption of fruits was protective for abdominal obesity (OR: 0.77; IC: -0.93 0.38 ), hypertriglyceridemia (OR: 0.76; IC: $0.35-0.96$ ) and presence of SM (OR: 0.78; IC: 0.39 -0.96).

\section{Cyclical influences on consumption}

The evidence and associations that try to explain the low consumption of fruits in different groups converge on the argument that the habits acquired by the previous generation are passed on to the next, and so from childhood to adolescence, adulthood and aging, and again to the next generation, as suggested by Figure 2. The current literature is already quite consistent about the transmission of the olfactory and taste characteristics of the mater-

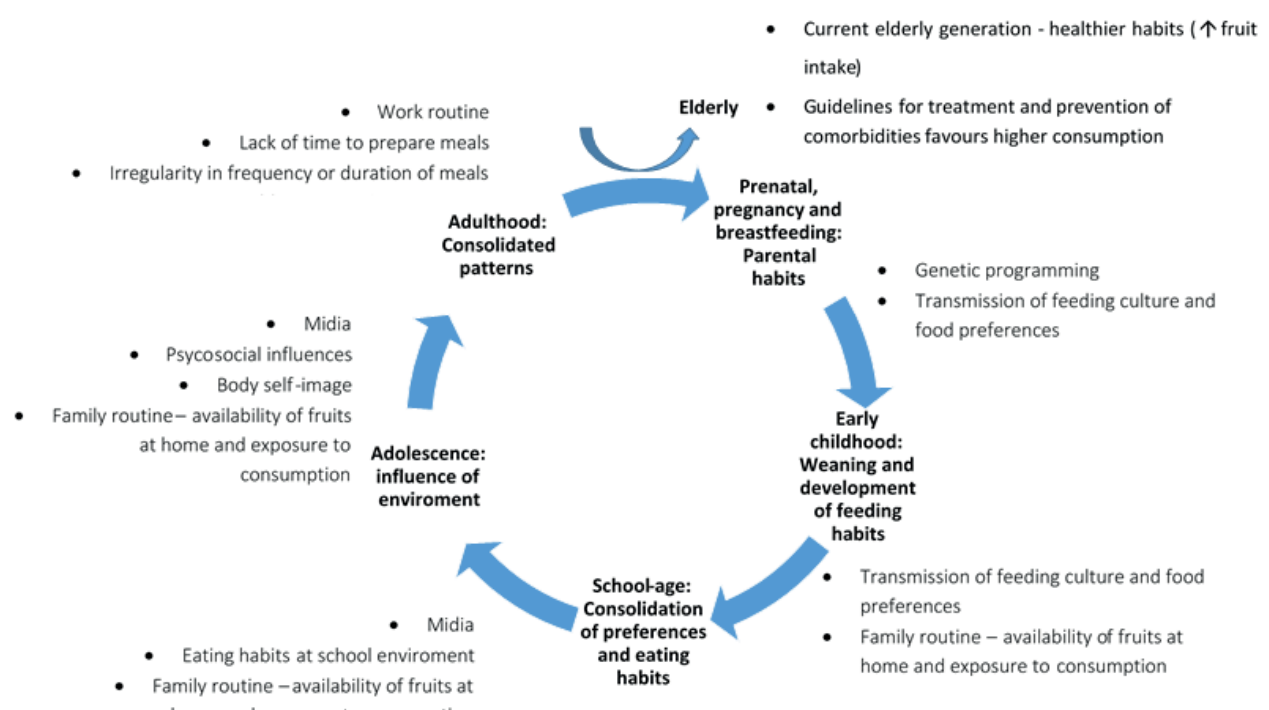

Figure 2: Model of influential factors in consumption habits across lifespan

nal diet via amniotic fluid - from the second quarter, when foetal gustatory and olfactory gestational receptors develop - and breast milk ${ }^{35}$. Several studies have shown that regular and frequent exposure of the mother to FV favours faster acceptance of these foods during the supplementary feeding of children and reduces the frequency and severity of feeding difficulties up to the age of seven years ${ }^{35,36,37}$. It has already been demonstrated that consumption and ex- 
posure to FV in this phase can have an effect on epigenetic aspects related to smell and taste, including perceptions of bitter/sweet/umami flavour and, in the future, influencing their food preferences ${ }^{35,38}$. In addition, from the second quarter, gestational maternal excessive weight gain is associated with an increase in BMI, fatness, inflammation, blood pressure and lipid profile in children younger than nine years ${ }^{1}$. If FV consumption has a significant contribution in the total consumption of dietary fibre, and fibre consumption on weight gain, one could assume that the lower the fruit consumption, the stronger would be the risk association.

The lack of exposure to food is considered, therefore, a barrier to consumption among children and adolescents, mainly. As for adults, FV consumption is influenced by the availability of such foods at home. However, the availability of these foods during this phase depends on family income, parental education and family routine, and families whose parents work away from home tend to have lower rates of consumption ${ }^{9,18,19.23}$. In addition, family, media habits and school meals are also strong influencing factors: there is evidence that snacks available in school vending machines were negatively associated with the consumption of fruit by teens ${ }^{1}$.

In relation to adults and seniors, the $\mathrm{POF}^{24}$ showed that women and older individuals with higher education presented more adequate consumption of fruits and vegetables, which may be associated with greater access to information and greater concern for health in this stratum of the population. Evidence suggests that younger individuals, single or living alone, and who spend most of the day working outside the home, have inadequate food consumption as a result of the lack of time for preparing vegetables, irregularity in frequency and mealtimes and poor availability of fruits in their working environments ${ }^{28}$. Some authors suggest that, for elderly individuals, the greater prevalence of adequate consumption can be influenced by healthier habits acquired in the past, prior to the current phenomenon of industrialized food, and by following guidelines received from health professionals, according to the overload of risk factors and the presence of comorbidities.

This review presents limitations, such as the absence of a systematic review of the bases and the difficulty in comparing the data, due to the different methodologies used by the studies selected and the lack of methodological standardization for the measurement of fruit consumption. However, it contributes to the field of public health by compiling data on consumption in all cycles of development and opens space for reflection about eating habits extended by subsequent stages of life, and for the development of action plans that seek to educate the population about such habits.

\section{REFERENCES}

1. Rede Nacional Primeira Infância (RNPI). Obesidade na primeira infância. Projeto Observatório Nacional da primeira infância. Fortaleza: Instituto da Infância; 2014.

2. Instituto Brasileiro de Geografi a e Estatística (IBGE). Pesquisa nacional de saúde 2013: percepção do estado de saúde, estilos de vida e doenças crônicas : Brasil, grandes regiões e unidades da federação. Rio de Janeiro: IBGE; 2014.

3. Soubry A, Murphy SK, Wang F, Huang Z, Vidal AC, Fuemmeler BF, et al. Newborns of obese parents have altered DNA methylation patterns at imprinted genes. Int J Obesity. 2015;(39):650-7. DOI: http://dx.doi. org/10.1038/ijo.2013.193

4. Brasil. Ministério da Saúde. Guia alimentar para a população brasileira. 2 ed. Brasília: 2014.

5. Santana AC. Consumo alimentar na gestação e ganho ponderal: um estudo de coorte de gestantes da zona oeste do município de São Paulo. Tese (Mestrado) - Universidade de São Paulo, Faculdade de Saúde Pública. São Paulo: 2013.

6. Castanho GKF, Marsola F, Mclellan KCP, Nicola M, Moreto F, Burini RC. Consumo de frutas, verduras e legumes associado à Síndrome Metabólica e seus componentes em amostra populacional adulta. Ciênc Saúde Coletiva. 2013;18(2):385-92. DOI: http://dx.doi.org/10.1590/S1413-81232013000200010,

7. Ciochetto CR, Orlandi SP, Vieira MFA. Consumo de frutas e vegetais em escolares da rede pública no Sul do Brasil. ALAN. 2012;62(2):172-8.

8. Sociedade Brasileira de Pediatria (SBP). Obesidade na infância e adolescência: Manual de Orientação. Rio de Janeiro: Departamento de Nutrologia; 2008.

9. Monticelli FDB, Souza JMP, Souza SB. Adolescent students' consumption of fruit, greens and vegetables. J Hum Growth Dev. 2013;23(3):331-7. DOI: http://dx.doi.org/10.7322/jhgd.69509

10. Malta DC, Silva Jr JB. Plano de Ações Estratégicas para o Enfrentamento das Doenças Crônicas Não Transmissíveis no Brasil após três anos de implantação, 2011-2013. Epidemiol Serv Saúde. 2014; 23(3):389-95. DOI: http://dx.doi.org/10.5123/S1679-49742014000300002

11. Castro MBT, Kac G, Sichieri R. Padrão de consumo alimentar em mulheres no pós-parto atendidas em um centro municipal de saúde do Rio de Janeiro, Brasil. Cad Saúde Pública. 2006;22(6):1159-70. DOI: http://dx.doi.org/10.1590/S0102-311X2006000600005

12. Baião MR , Deslandes SF. Práticas alimentares na gravidez: um estudo com gestantes e puérperas de um complexo de favelas do Rio de Janeiro ( RJ, Brasil). Ciênc Saúde Coletiva. 2010;15(Supl. 2):3199206. DOI: http://dx.doi.org/10.1590/S1413-81232010000800025 
13. Cagliari MPP, Paiva AZ, Queiroz D, Araújo ES. Consumo alimentar, antropometria e morbidade em pré--escolares de creches públicas de Campina Grande, Paraíba. Nutrire Rev Soc Bras Aliment Nutr. 2009;34(1):29-43.

14. Grillo LP, Klitzke CA, Campos IC, Mezadri T. Riscos Nutricionais De Escolares Pertencentes a Famílias de Baixa Renda do Litoral Catarinense. Texto Contexto Enferm. 2005; 14(Esp.):17-23. DOI: http://dx.doi. org/10.1590/S0104-07072005000500002

15. Rauber F, Hoffman DJ, Vitolo MR. Diet quality from pre-school to school age in Brazilian children: a 4-year follow--up in a randomised control study. Br J Nutr. 2014;111(3):499-505. DOI: : http://dx.doi.org/10.1017/ S0007114513002857

16. Bueno MB, Fisberg RM, Maximino P, Rodrigues GP, Fisberg M. Nutritional risk among Brazilian children 2 to 6 years old: a multicenter study. Nutrition. 2013;29(2):405-10. DOI: http://dx.doi.org/10.1016/j. nut.2012.06.012

17. Toral N, Slater B, Cintra IP, Fisberg M. Comportamento alimentar de adolescentes em relação ao consumo de frutas e verduras. Rev Nutr. 2006; 19(3): 331-40.

18. Bigio RS, Verly Junior E, Castro MA, César CLG, Fisberg RM, Marchioni DML. Determinantes do consumo de frutas e hortaliças em adolescentes por regressão quantílica. Rev Saúde Pública. 2011;45(3): 448-56. DOI: http://dx.doi.org/10.1590/S0034-89102011005000023

19. Rieth MA, Moreira MB, Fuchs FD, Moreira LB, Fuchs SC. Fruits and vegetables intake and characteristics associated among adolescents from Southern Brazil. Nutr Jl. 2012;11:95. DOI: http://dx.doi. org/10.1186/1475-2891-11-95

20. Toral N, Slater B, Silva MV. Consumo alimentar e excesso de peso de adolescentes de Piracicaba, São Paulo. Rev Nutr. 2007;20(5):449-59. DOI: http://dx.doi.org/10.1590/S1415-52732007000500001

21. Dumith SC, Muniz LC, Tassitano RM, Hallal PC, Menezes AM. Clustering of risk factors for chronic diseases among adolescents from Southern Brazil. Prev Med. 2012;54(6):393-6. DOI: http://dx.doi.org/10.1016/j. ypmed.2012.03.014

22. Mello MVFA, Andrade RF, Otero LM, Cárdenas AMC, Silva ER. Risk factors associated with diabesity in primary school students in the Amazon region of Brazil. Invest Educ Enferm. 2013;31(3): 433-41.

23. Muniz LC, Zanini RV, Schneider BC, Tassitano RM, Feitosa WMN, González-Chica DA. Prevalência e fatores associados ao consumo de frutas, legumes e verduras entre adolescentes de escolas públicas de Caruaru, PE. Ciênc Saúde Coletiva. 2013;18(2):393-404. DOI: http://dx.doi.org/10.1590/S141381232013000200011

24. Souza AM, Pereira RA, Yokoo EM, Levy RB, Sichieri R. Alimentos mais consumidos no Brasil: Inquérito Nacional de Alimentação 2008-2009. Rev Saúde Pública. 2013;47(1 Supl):190S-9. DOI: http://dx.doi. org/10.1590/S0034-89102013000700005

25. Jaime PC, Figueiredo ICR, Moura EC, Malta DC. Fatores associados ao consumo de frutas e hortaliças no Brasil, 2006. Rev Saúde Pública. 2009;43(Supl. 2):57-64. DOI: http://dx.doi.org/10.1590/S003489102009000900008

26. Iser BPM, Yokota RTC, Sá NNB, Moura L, Malta DC. Prevalência de fatores de risco e proteção para doenças crônicas nas capitais do Brasil - principais resultados do Vigitel 2010. Ciênc Saúde Coletiva. 2012;17(9):2343-56. DOI: http://dx.doi.org/10.1590/S1413-81232012000900015

27. Brasil. Ministério da Saúde. Vigitel Brasil 2013: vigilância de fatores de risco e proteção para doenças crônicas por inquérito telefônico. Brasília: Ministério da Saúde, Secretaria de Vigilância em Saúde; 2014.

28. Palma RFM, Barbieri P, Damião R, Poletto J, Chaim R, Gimeno SG, et al. Fatores associados ao consumo de frutas, verduras e legumes em Nipo-Brasileiros. Rev Bras Epidemiol. 2009;12(3):436-45. DOI: http://dx.doi.org/10.1590/S1415-790X2009000300012

29. Mondini L, Moraes SA, Freitas ICM, Gimeno SGA. Consumo de frutas e hortaliças por adultos em Ribeirão Preto, SP. Rev Saúde Pública. 2010;44(4):686-94. DOI: http://dx.doi.org/10.1590/S003489102010000400012

30. Ramalho AA, Dalamaria T, Souza OF. Consumo regular de frutas e hortaliças por estudantes universitários em Rio Branco, Acre,Brasil: prevalência e fatores associados. Cad. Saúde Pública. 2012;28(7):140513. DOI: http://dx.doi.org/10.1590/S0102-311X2012000700018

31. Amado TCF, Arruda IKG, Ferreira AR. Aspectos alimentares, nutricionais e de saúde de idosas atendidas no Núcleo de Atenção ao Idoso - NAI, Recife/ 2005. ALAN. 2007;57(4):366-72.

32. Viebig RF, Pastor-Valero M, Scazufca M, Menezes PR. Consumo de frutas e hortaliças por idosos de baixa renda na cidade de São Paulo. Rev Saúde Pública. 2009;43(5):806-13. DOI: http://dx.doi.org/10.1590/ S0034-89102009005000048

33. Sartorelli DS, Franco LJ, Cardoso MA. High intake of fruits and vegetables predicts weight loss in Brazilian overweight adults. Nutr Res. 2008;28(4):233-8. DOI: http://dx.doi.org/10.1016/j.nutres.2008.02.004 
34. Perozzo G, Olinto MTA, Dias-da-Costa JS, Henn RL, Sarriera J, Pattussi MP. Associação dos padrões alimentares com obesidade geral e abdominal em mulheres residentes no Sul do Brasil. Cad Saúde Pública. 2008;24(10):2427-39. DOI: http://dx.doi.org/10.1590/S0102-311X2008001000023

35. Ventura AK, Worobey J. Early Infl uences on the Development of Food preferences. Curr Biol. 2013;23(9):R401-8. DOI: http://dx.doi.org/10.1016/j.cub.2013.02.037

36. Trout KK, Wetzel-Effi nger L. flavor learning in utero and its implications for future obesity and diabetes. Curr Diab Rep. 2012;12(1):60-6. DOI: http://dx.doi.org/10.1007/s11892-011-0237-4

37. Cooke L, Fildes A. The impact of $\mathrm{fl}$ avour exposure in utero and during milk feeding on food acceptance at weaning and beyond. Appetite. 2011;57(3):808-11. DOI: http://dx.doi.org/10.1016/j.appet.2011.05.317

38. Mennella JA. Ontogeny of taste preferences: basic biology and implications for health. Am J Clin Nutr. 2014;99(3):704S-11. DOI: http://dx.doi.org/10.3945/ajcn.113.067694

39. Brasil. Ministério da Saúde. Secretaria de Vigilância em Saúde. Vigitel Brasil 2014: Vigilância de fatores de risco e proteção para doenças crônicas por inquérito telefônico. [cited 2015 Aug 24] Available from: http://portalsaude.saude.gov.br/images/pdf/2015/abril/15/PPT-Vigitel-2014-.pdf.

40. Ferreira PM, Papini SJ, Corrente JE. Diversidade de padrões alimentares em idosos: um novo cenário? Rev Nutr.. 2014;27(1):67-79. DOI: http://dx.doi.org/10.1590/1415-52732014000100007

This article is distributed under the terms of the Creative Commons Attribution 4.0 International License (http://creativecommons.org/licenses/by/4.0/), which permits unrestricted use, distribution, and reproduction in any medium, provided you give appropriate credit to the original author(s) and the source, provide a link to the Creative Commons license, and indicate if changes were made. The Creative Commons Public Domain Dedication waiver (http://creativecommons.org/publicdomain/zero/1.0/) applies to the data made available in this article, unless otherwise stated.

\section{Resumo}

Introdução: A obesidade atinge mais da metade da população adulta brasileira e se correlaciona com o desenvolvimento de doenças crônicas e psicossociais. O consumo de frutas, legumes e verduras (FLV) é fator de proteção para obesidade, porém seu consumo está frequentemente abaixo das recomendações.

Objetivo: Identificar a situação de consumo de frutas no Brasil nos ciclos de desenvolvimento humano, bem como dados de associação do consumo com excesso de peso.

Método: Revisão de literatura não sistemática nas bases de dados BVS, do período de 2005 a 2015. Foram selecionados 23 trabalhos em língua portuguesa e inglesa, segundo desenho e grupo populacional. Foram selecionados apenas coortes e cortes transversais realizados no Brasil. Foi considerado consumo de FLV adequado de $400 \mathrm{~g} /$ dia ou frequência de 5 porções/dia (3 porções/dia de frutas), e excesso de peso segundo cada faixa etária e ciclo de desenvolvimento.

Resultados e discussão: O consumo médio encontrado para gestantes foi de $350 \mathrm{~g} /$ dia. Foi encontrada relação inversa entre o consumo de fibras totais e o ganho ponderal gestacional. A média de consumo adequado de crianças e adolescentes se manteve entre 30 e $40 \%$, com redução de consumo conforme aumento da idade. Dados da Vigitel entre 2006 e 2014 demonstram aumento na prevalência de consumo adequado de FLV por adultos e idosos conforme sexo, idade e escolaridade. O consumo adequado triplicou neste período. Houve associação entre o consumo de frutas e a perda de peso, risco aumentado de obesidade, obesidade abdominal, hipertrigliceridemia e presença de SM.

Conclusões: Há evidências de baixas prevalências de consumo adequado de FLV em todas as regiões do Brasil e grupos etários, maiores entre as mulheres e conforme o avanço da idade, escolaridade e nível socioeconômico. O consumo adequado de frutas se correlaciona à perda de peso e/ou controle do ganho ponderal dos indivíduos.

Palavras chave: Frutas, consumo, obesidade/excesso de peso, Brasil, gestação, infância, adolescência, idosos, adultos. 